\title{
Post-Earthquake Reconstruction in Nepal: Conformance the Assumptions, Actions, and Achievements
}

\author{
Raj Kumar Bhattarai, Ph.D. \\ Associate Professor, Nepal Commerce Campus, T.U. \\ Email: raj@ncc.edu.np
}

\begin{abstract}
Post-earthquake reconstruction works is a consequential mission. The principal premises of the mission are the goal of speedily rebuilding, well-structured plans, extensive local resources mobilization, and commissioning leadership in the reconstruction and rehabilitation works. Nepal's pluralistic character, political upheavals, and shortcoming of resources are real-time challenges to mission accomplishment. Congruence of the assumptions, actions, and achievements concerning physical, socio-psychological, cultural, and financial dimensions of vulnerabilities is of foremost significance because the social acceptance and/or rejection is a critical determinant of the mission accomplishment. This study aims to determine the congruence level of assumptions, actions, and accomplishments concerning the managerial process activities of the National Reconstruction Authority, which are addressing the concerns of reconstruction work, national interest, and social justice. An exploration on the Authority's attention to the reciprocal eco-cultural resiliency measures has also been made to find a balance among the concerns. The study begins with reviewing the Acts, policies, directives, standards, and working procedures concerning the reconstruction works. The Authority's annual reports and decisions of the Appellate Committee are taken as the sources of information. A matrix form of NRA's process activities, key assumptions, major actions, and notable accomplishments is prepared for analysis. Matchmaking of the assumptions with the actions and achievements has been made, and the level of their congruence assessed. The level of congruence among the assumptions, actions, and achievements concerning the consequential mission is found unsatisfactory. There is an absence of process activities concerning the reciprocal eco-cultural resiliency, national interest, and social justice. Partially adapted the process activities and corresponding assumptions, actions, and achievements seems insufficient to achieve the envisioned transformation in the disaster-affected districts. Deeply rooted selfinterest of the people and institutions associated with the consequential mission stands as a major challenge in the process of reconstruction.
\end{abstract}

Keywords: congruence measurement, performance evaluation, reconstruction policy, eco-cultural resiliency, grievance handling 


\section{Introduction}

National Reconstruction Authority (NRA) was established on $25^{\text {th }}$ of December 2015 under a special Act. The establishment was just after eight months of the first earthquake of 7.6 Richter scale, which had occurred on $25^{\text {th }}$ of April 2015. From the $27^{\text {th }}$ day of December NRA had started its jobs in the earthquakeaffected districts.

The Authority's vision is 'well-managed resilient settlements and prosperous society.' Its mission statement is 'to provide leadership for completing reconstruction and resettlement with a clear plan through the optimum use of local labor, resources and means as well as international support.' The vision and mission statements ensure for the earthquake-damaged society's recovery and prosperity. Moreover, the authority has declared to promote national interest and provide social justice by completing the reconstruction works of the damaged-structures as well as rehabilitation and translocation of the displaced people in a planned and sustained manner. It has strategic intent of optimum utilization of local resources mobilization.

The 'An Act Made to Provide for Reconstruction of the Earthquake Affected Structures, 2015 (referred hereinafter as Reconstruction Act)' has specified its jurisdiction, functions, and also granted the authority to move ahead to achieve its objectives. The preamble of the Act has anticipated national interest promotion, and social justice assurance in addition to the reconstruction and translocation works. The jurisdiction covers all the 32 earthquake-affected districts - 14 most affected, 11 moderately affected and seven least affected districts. The most affected districts are Dolakha, Sindhupalanchowk, Gorkha, Nuwakot, Rasuwa, Dhading, Kavrepalanchowk, Ramechhap, Bhaktapur, Okhaldhunga, Sindhuli, Lalitpur, Kathmandu, and Makawanpur. Affected districts are Lamjung, Chitwan, Tanahu, Khotang, Syangja, Palpa, Baglung, Gulmi, Solukhumbhu, Kaski, and Parbat. Similarly, the least affected districts are Myagdi, Arghakhanchi, Nawalparashi-2, Bhojpur, Dhankuta, and Sankhuwasabha.

\section{Composition of NRA}

The NRA is organized under the Reconstruction Act. The Act has made a provision for various committees. There is an Advisory Council (राष्ट्रिय पुननिर्माण परामर्श परिषद) consisting ex-Prime Ministers and other high-profile representatives to advise the Government of Nepal and the Steering Committee (निर्देशक समिति). The Board of Directors composed of 11 members is working above the Executive Committee (कार्यकारी समिति). The Executive Committee formed under the leadership of the Chief Executive Officer is carrying out the daily activities and also preparing reconstruction policy, plans, budgets, and so on. There is also provision of Development Assistance and Facilitation Committee (विकाश सहायता समन्वय तथा सहगजिकरण समिति) in assumptions of making the entire reconstruction and rehabilitation works effective and transparent. The District Coordination Committee (जिल्ला समन्वय समिति) is coordinating the tasks carrying out by the NRA in the earthquake-affected districts. Three-members' Appellate Committee (पुनरावेदन समिति) is making judgments on the grievances filed against the NRA's decisions and actions. A separate Reconstruction Fund (पुननिर्माण कोष) is available for it.

The Authority has adopted a divisional hierarchical structure at Kathmandu to carry out its regular activities. Additionally, the Authority hadtailored the functional and project structures in addition to the networks with different line ministries. It has five divisions with three Central Project Implementation Units. The five divisions consist of Planning and Budget Management; Human Resource Management; Policy, Monitoring, Evaluation and Coordination; Heritage Protection, Public Building, and Infrastructure; and House, Settlement, and Local Infrastructure. The Project Implementation Units consists of grant Management and Local Infrastructure Project, Building, and Education (see Appendix 2). It has expanded its structure at the district level as well.

The organization structure has created a pyramid type of reporting relationship at the central level structure, district level structure, and center and district level structures. The pyramid creates a hierarchy, which requires a strong chain of command. Effectiveness of the chain of command needs to ensure a speedy reconstruction works. It is obvious that reconstruction/rehabilitation works seek to minimize all types of 
vulnerabilities and attempt to enhance socio-cultural cohesion (McCaughey, Daly, Mundir, Mahdi, \&Patt, 2018) in the affected districts.

\section{Research questions}

The tardy pace of reconstruction works and absence of notable activities regarding the national interest and social justice are two significant issues of public goods. The NRA had to be set-up just after the earthquake, but it spent eight months from the earthquake to be established under the Act. It has completed one million above household surveys but registered about 635,000 grievances. The grievances were affected persons' feeling of being excluded and/or inaccurate measurement of the earthquake-caused loss and damage of individual property. In fact, the reconstruction work has not been completed yet, but the tenure of the NRA is going to complete soon. In this outlook, the following questions are set forth.

- Whether the managerial process activities of the Authority integrate all the concerns of reconstruction work, national interest, and social justice?

- Are the process activities instrumental in bringing change and development in eco-cultural structures in the affected districts?

- To what extent has the reconstruction mission enhanced reciprocal eco-cultural resiliency ${ }^{1}$ measures in the affected districts?

- What new knowledge has the consequential mission generated to address likely vulnerabilities, hazards, and resiliency?

\section{Objectives}

The general objective is to assess the level of congruence among the assumptions, actions, and achievements of the Authority's works in order to generate new knowledge of the vulnerability, hazard, and eco-cultural resiliency. Followings are the specific objectives of this study:

- To determine the conformance in managerial process activities of the Authority that are addressing the concerns of reconstruction work, national interest, and social justice;

- To assess the one to one conformance within the process activities in bringing change and development in eco-cultural structures in the affected districts;

- To ascertain the extent of reciprocal eco-cultural resiliency measures has the reconstruction mission enhanced in the affected districts; and

- To generate new knowledge for further substantiation that become useful to enhance postdisaster reconstruction works.

\section{Delimitations}

Scope of this study is confined within the purview of NRA's process activities. The assumptions, actions, and accomplishments concerning the national interest, social justice, and resiliency are insufficiently addressed in the paper because the process activities could not cover those concerns and the Authority's works were concentrated on the reconstruction of damaged-structures.

The lockdown, due to COVID-19 pandemic, prevented field visits and on ground key informant interviews. NRAs Website and Annual Progress Reports of 2073/74, 2074/75, 2075/76 remained the sources of information. Even though the actions and achievements of the initial stage are missing in the absence of progress report of the year 2072/73.

Weight to the assumptions, actions, and achievements could not be assigned because of missing weight at their origin i.e. the NRAdid not mention relative weight to the items of its decisions, and accomplishments. Therefore, there is no adjustment on the reciprocity and mutuality of the managerial process activities. The

1 The term 'reciprocal eco-cultural resiliency' refers to the condition of mutuality, shared responsibility, and inclination towards the economic and cultural plasticity of a society. The plasticity refers to the quality of economic actors and cultural adaptors for reshaping and regaining their well-beings in a continuum of change. 
Reconstruction Act also remained silent on the relative significance of the Authority's functions, duties, and power. Therefore, the congruence level does not reflect the relative weight of the assumptions, actions, and achievements. It is calculated only on a nominal number of statements referring to the assumptions, actions, and achievements.

\section{Methodology}

The AAA approach is original in congruence analysis in a consequential mission. The existing approaches are focused on the standards (objectives/goals) and actual results but missing a key aspectthe status of required decisions/actions to attain the objectives/goals - of the mission. The results are not only based on the accuracy of objectives/goals but also depends on the subsequent decisions/actions of the key actors. There are sufficient evidences of objectives/goals failures in absence of necessary subsequent actions thereon.

The tendency of putting blame on the environmental uncertainty by the actors requires to focus on their deliberateness of taking necessary actions as expected/assumed by the mission. As being a new approach, it is obvious to expect more comments and discussion. Accordingly, this explorative-evaluative study began with reviewing the Acts, policies, directives, and working procedures concerning the reconstruction works(see Appendix 1). All of the documents were assessed electronically and read thoroughly to find the assumptions/expectations about the mission. The standards and guidelines issued for quality and quantity were also noted along with the assumptions. The managerial process activities consisting the activities of planning, organizing, executing, monitoring, grievance handling, advising to the government, among others, were the basic criteria for reviewing the documents.

The preamble of the Reconstruction Act, specifically, the reconstruction work, national interest, and social justice are the basis of the review in view of 'no one' and 'no activity' can go beyond the Act; and compliance to the Act is necessary for all the concerned to the reconstruction mission. The review was based on the managerial process activities. Reflections of the works and supports of all parties involved is seen in the Authority's annual progress reports and the decisions of the Appellate Committee.Matchmaking of the assumptions with the actions and achievements has been made to determine the sequential congruence.

A matrix form of process activities and key assumptions, major actions, and notable achievements is prepared. A list of its process activities is determined on the basis of the functions, duties, and responsibility of the NRA specified in the Reconstruction Act. The key assumptions, derived from the Act, are linked with the corresponding managerial process activity. The actions and accomplishments are taken from the NRA's annual progress reports. The major actions taken, and notable achievements made by the NRA are matched with the corresponding process activity and key assumptions.

The entire data and information are obtained from the NRA's annual progress reports along with the Act, directives, standards, and working procedures. In fact, the assumptions, actions, and achievements are solely and finally have been centered to the NRA; because the Authority is primarily responsible to address the Reconstruction Act.

The calculation of congruence level is based on the following formula developed for the purpose of this study. The nominal scale is used to measure the assumptions, actions, and achievements in absence of weight at the source - the regulatory documents and the annual progress reports of the NRA. The range of value is 0 to 1 , which is measured in nominal scale on one to one basis i.e. a value of 1 was given to each assumption; similarly, a value of 1 was given if notable action(s) to the assumption was seen; and a value of 1 was given if notable outcome(s) of the action was seen; otherwise, value of zero was assigned in the respective cell of the matrix.

$$
C_{l}=\sum \frac{A_{c}+A_{e}+A_{r}}{3 A_{c}} \times 100
$$

Where,

$C_{l}=$ Level of (nominal) congruence 
$A_{c}=$ Committed assumptions

$A_{e}=$ Enacted decisions/actions

$A_{r}=$ Resulted achievements

The traditional practice of introducing Acts and preparing plans and policies thereof, are missing the strength of assigning weight to their assumptions, commitments, expectations/ goals, and entire actions that are reflecting the Acts, policies, and plans. This is the key issue this paper intends to bring in front for further discussion. For instance, the practice of inclusion of a few laudable words and phrases like national interest, social justice, resiliency, and so on without their indicators at sources, cannot help the researchers to set and explain suitable benchmarks and indicators.

\section{Analysis}

The earthquake took the lives of 8,790 people and injured more than 22,300 people. The detailed household survey shows the damage of about eight lakhs private houses; 2,656 government houses severely damaged, and 3,622 houses partially damaged. Similarly, 8,680 schools and dozens of university buildings were damaged by the tremors. At least 753 archaeological structures, 1,200 Gumbas, 1,197 health institutes, 4,545 water supply structures, 3 strategic roads and 50 rural/village roads required urgent reconstruction (National Reconstruction Authority [NRA], 2017).

The government of Nepal established NRA just after eight months of the earthquake under the Reconstruction Act 2015. The Act has shaped the scope, functions, duties and power of the Authority. The Act further provides the foundation of the Authority's entire process activities concerning the work of reconstruction, resettlement, translocation, national interest and social justice.

The Authority's mission statement addresses the preamble of the Reconstruction Act. The ground reality is an excessive dependence on international donors' support for reconstruction works. Maintaining a harmony of the commitment to national interest promotion and social justice enrichment and a dire need of international support seem a tough job for the executives at NRA. The notions of optimum utilization of local knowledge, skills, and resources in favor of national interest and social justice appears laudable in the paper, but it becomes very hard to realize in practice because international support includes conditions. There is a certain interest in every international support, and obviously the supporter is expecting certain behavior and outcome from its beneficiary. Sometimes, the donors' interests and activities are dominating the beneficiary's interests and activities. For instance, there are dozens of reconstruction projects carried out by international agencies on their own (see Annual Reports of the NRA).

\section{Assessment of the assumptions, actions, and achievements}

This paper uses the word 'assumption' to refer to its functions, duties, and authority granted by the Reconstruction Act. The assumptions are also the NRA's functions, duties and responsibilities towards the successful completion of the reconstruction work, promotion of national interest, and assurance of social justice as envisioned by the Act. It is believed that the assumptions are accepted as true or certain to happen in the course of reconstruction. In the same line the NRA's vision, mission statement, acts, rules, policies, directives, standards, and working procedures are clearly reflecting the assumptions and commitments.

NRA's major reconstruction process activities - surveying, designing, directing/leading, planning, capacitating/organizing, executing, coordinating, evaluating/monitoring, grievance handling, and advising the government - are determined under the purview of the Act. Corresponding assumptions to the process activities are assessed on the basis of the NRA's actions - functions, duties, and power. The outcomes of the actions are considered as achievements. The linkages of the major actions and notable achievements to the corresponding assumptions are displaying the meeting or missing of a congruence in the reconstruction works. The number and letter in parenthesis under the column of 'basic assumptions' refer to the Section of the Reconstruction Act, 2015. 


\section{Surveying}

Determination of loss and damage, technical inspections of damaged and/or risky physical structures as well as identification of locations for rehabilitation and translocation of affected people are basic assumptions/expectations from the NRA. The actions of information collection, household and geological surveys resulted in a number of notable achievements. Following table provides a summary of its survey activities.

Table 1

Surveying: Assumptions, Actions, and Achievements

\begin{tabular}{|c|c|c|}
\hline Basic assumptions & Major actions & Notable achievements \\
\hline $\begin{array}{l}\text { Determine, or caused to be } \\
\text { determined the damage caused by } \\
\text { the earthquake ( } 4.1 . a)\end{array}$ & $\begin{array}{l}\text { Information collected about } \\
\text { the death and injury of people, } \\
\text { damage of structures }\end{array}$ & $\begin{array}{l}\text { Number of deaths: } 8790 \\
\text { injured people: } 22,300 \\
\text { - } \quad \text { Listed beneficiaries till } \\
\text { 01/03/2077: } 832,408\end{array}$ \\
\hline $\begin{array}{l}\text { Makes, or cause to be made, } \\
\text { technical examination of the } \\
\text { damaged or unsafe physical } \\
\text { structures (4.1.q) }\end{array}$ & $\begin{array}{l}\text { Household surveys completed till } \\
01 / 03 / 2077: 1,037,291\end{array}$ & $\begin{array}{l}\text { Damaged personal homes: almost } \\
800,000 \text {; and other structures: } \\
22,703\end{array}$ \\
\hline $\begin{array}{l}\text { Identifies appropriate sites for } \\
\text { integrated settlements, house } \\
\text { polling, rehabilitation and } \\
\text { translocation(4.1.g) }\end{array}$ & $\begin{array}{l}\text { Geological surveys in } 1060 \\
\text { villages were completed till FY } \\
2075 / 76\end{array}$ & $\begin{array}{l}\text { Determined for translocation of } \\
283 \text { villages; necessity of safety } \\
\text { measures in } 305 \text { villages; and } 472 \\
\text { villages found secured }\end{array}$ \\
\hline
\end{tabular}

\section{Designing}

The NRA has designed and issued various guiding and regulating documents. Similarly, the designs for rural settlements are in effect but such designs are not ready for urban settlements till the end of 2075/76. There were 1,320 Gumbas damaged from the earthquake, but still (2074/75) there were no modalities prepared for the reconstruction of those Gumbas.

While designing the reconstruction and rehabilitation projects, the NRA could not categorize the projects as self-executable and non-self-executable. It could not include any schemes/models to enhance eco-cultural resiliency in consideration of future disasters in the regions. It has been attentive to build the resiliency of physical structures but not to build the economic and cultural structures in the districts. The study could not find any specific modality selected for collaborative reconstruction work except the agreements. Following table provides a summary of its actions and accomplishments.

Table 2

Designing: Assumptions, Actions, and Achievements

\begin{tabular}{|c|c|c|}
\hline Basic assumptions & Major actions & Notable achievements \\
\hline Designs organization structure (18) & $\begin{array}{l}\text { - Organized the Authority } \\
\text { at Kathmandu } \\
\text { - Opened } 22 \text { secretariats } \\
\text { in the affected districts }\end{array}$ & $\begin{array}{l}\text { Presence of a mechanism of } \\
\text { command and coordination }\end{array}$ \\
\hline
\end{tabular}


$\frac{\text { Basic assumptions }}{\text { Prepares designs for residential homes and }}$ other structures (4.1.g, 4.1.s)
Sets standards for integrated settlements, house pooling, rehabilitation and translocation including land procurement (4.1.g, 4.1.s)

Prepares designs for the integrated settlements, house pooling, rehabilitation and translocation (4.1.g, 4.1.s)

Develops norms for development of integrated settlement, house pulling, rehabilitation and translocation (4.1.g) i.e. formulates policies, rules, regulations, directives

Selects an appropriate modality to carry out the reconstruction work in collaboration with the governmental, private or nongovernmental sector, community or with any foreign organization based in Nepal (4.1.m) rules (1), standards (1), directives (2), and working procedures (15)
Notable achievements

- Prepared 34 design catalogues of private residential homes

- Prepared designs for other structures including government buildings, academic institutions, hospitals At least 1 standard issued Prepared foundation for controlling quantity and quality of the works

- Associated with Urban Development Ministry, NRN for first model village development

- Feasibility studies continues for translocation of villages

- Readiness for initiation to shift Larpak to Gupsipakha in Gorkha district

- 56 studies from Ministry of Urban Development and 5 from NRA

At least 20 guiding and Decisions and actions regulating documents consisting the Act (1), processes related to reconstruction facilitated

Note: The blank cells indicate no major actions and achievements regarding the corresponding assumptions

\section{Planning}

The NRA could not deliver a robust plan of actions on its own. Mainly, it involved granting approval to the projects submitted by others. There were more than 785,603 grants and assistance agreements, which included hundreds of conditions. The conditions seem very challenging for the NRA to provide real leadership in the reconstruction process.

In the progress reports, NRA has provided information about others' projects/plans it had approved but the reports have not provided information about the projects/plans it had carried out on its own. Similarly, there is no concrete plan of actions for livelihood improvement as such; however, the ministries and NGOs were providing training programs for livelihood. Likewise, it could not introduce specific social security programs for those who had been disabled, single-family, elderly people, homeless children, and 
Issue 1 May/June 2020

similar others.

There are no more actions and achievements regarding prioritizing the reconstruction works and preparing plans for integrated settlements, house pooling, rehabilitation and translocation. Plans for promotion of national interest and social justice are far from its process activities.

Table 3

Planning: Assumptions, Actions, and Achievements

\begin{tabular}{ccc}
\hline Basic assumptions & Major actions & Notable achievements \\
\hline
\end{tabular}

Fixes priority of the reconstruction (4.1.c)

Formulate plans for integrated settlements,

house pooling, rehabilitation and translocation

(4.1.g)

Prepares programs related to human resource

Determined the training

need for technicians and

workers

Types, contents, duration, recipients, and providers of training as required for education, health, agriculture, industry, employment, and reconstruction and rehabilitation (4.1.j)

Provide budget and other resources to the agencies that are getting assignment of reconstruction (NRA Website: mandate) Approves such policies, plans, budget and programs with schedule of operations (4.1.d)

- Invited/obtained projects from different agencies

- Received-plans presented in the Executive Meeting for their approval

Note: The blank cells indicate no major actions and achievements regarding the corresponding assumptions

\section{Capacitating/organizing}

The NRA adequately filled the positions in its hierarchy. However, its restructuring, as reflected in the report of 2074/75, indicates that the Central Project Implementation Units working under different ministries (Ministry of Federal Affairs and Local Development, Ministry of Education, Ministry of Health, and Ministry of Urban Development) and District Project Implementation Units were brought under the command of NRA. There were integration/merger and removal of other implementation units at central and district levels. The Units were working under dual command - command of the ministries and the NRAwas not effective enough. This type of restructuring/merger indicates that the NRA had no clear concept of its own organization design.

The Authority did not build personal homes for the beneficiaries, instead, it asked them to construct their houses according to its design. The amount of grants for personal house reconstruction was Rs. 300,000 and for retrofitting Rs. 100,000. The amount of personal home construction was provided in three tranches, but the amount of retrofitting in two equal tranches. The Authority intended to support the beneficiaries in the financing, but it could not facilitate the beneficiaries in getting loans on subsidized interest rates.

Financial resource mobilization was not moving through one window. It was moving through the NRA, the government and beyond. The NRA's annual report of 2074/75 shows that Rs. 41.99 billion 
(19.02\%) was from outside of the government's budget. Similarly, there was Rs. 78.4 billion (35.51\%) amount appearing in the government budget but it was for direct payment i.e. on a budget off treasury. The donors were mobilizing the amount from their own channels. Such practices are other examples of shortcoming/challenges of the NRA in the process of directing/leading and controlling the reconstruction process activities.

The NRA indicates that the issues of land ownership is one of the major challenges in the selection and acquisition of land. The NRA's requirements and local norms/standards are facing incompatibility. Following table provides a summary regarding the activity of capacitating/organizing.

Table 4

Capacitating/organizing: Assumptions, Actions, and Achievements

\begin{tabular}{|c|c|c|}
\hline Basic assumptions & Major actions & Notable achievements \\
\hline $\begin{array}{l}\text { Brings about financial resources for } \\
\text { reconstruction (4.1.p) }\end{array}$ & $\begin{array}{l}\text { - Agreements made for } \\
\text { grants and assistance: } \\
785,603 \\
\text { - Number of grants } \\
\text { agreements: FY 2072/73: } \\
278,880 ; \text { FY 2073/74: } \\
629613 ; \text { FY 2074/75: } \\
722,019 \\
\text { Grants distribution } \\
\text { for personal homes } \\
\text { construction }\end{array}$ & $\begin{array}{l}\text { - } 2072 / 73 \text { budget Rs. } 74 \text { billion } \\
\text { (spent 30.36\%); 2073/74 } \\
\text { budget Rs. 112.58 billion } \\
\text { (spent 44.14\%); } 2074 / 75 \\
\text { budget Rs. } 151.17 \text { (spent } \\
\text { 75.93\%); 75/76 Rs. } 138.43 \\
\text { billion (spent } 64.61 \% \text { ) } \\
\text { - Availability of grants for } \\
\text { personal homes construction }\end{array}$ \\
\hline $\begin{array}{l}\text { Acquires lands or assigns the } \\
\text { responsibility to anybody for the } \\
\text { implementation of plans or programs } \\
\text { including reconstruction, integrated } \\
\text { settlement, house pooling plans or } \\
\text { programs (4.1. f) }\end{array}$ & $\begin{array}{l}\text { - Worked for land } \\
\text { readjustment, and guided } \\
\text { for land development } \\
\text { - Worked for at least } 50 \\
\text { integrated settlements }\end{array}$ & $\begin{array}{l}\text { All necessary arrangements made } \\
\text { for translocation of } 756 \text { families }\end{array}$ \\
\hline $\begin{array}{l}\text { Mobilizes NGOs, private sector or } \\
\text { community for reconstruction (4.1.1) }\end{array}$ & $\begin{array}{l}\text { Mobilized the banks and } \\
\text { financial institutions in the } \\
\text { affected districts }\end{array}$ & $\begin{array}{l}\text { Loans and grants distribution } \\
\text { process facilitated }\end{array}$ \\
\hline $\begin{array}{l}\text { Provides requisite budget and other } \\
\text { resources to the body responsible for } \\
\text { reconstruction ( } 4.1 . \mathrm{k}) \\
\text { Builds or caused to be built, capacity }\end{array}$ & & \\
\hline $\begin{array}{l}\text { of the bodies involved in the } \\
\text { reconstruction works ( } 4.1 .0 \text { ) } \\
\text { Develops capacity, or caused to }\end{array}$ & & \\
\hline $\begin{array}{l}\text { develop the capacity of the agencies } \\
\text { involved in reconstruction (NRA }\end{array}$ & & \\
\hline Website: mandate) & & \\
\hline
\end{tabular}

Note: The blank cells indicate no major actions and achievements regarding the corresponding assumptions 


\section{Directing/leading}

The design/modality of reconstruction works involved multiple parties like the government's ministries, departments, local authorities, NGOs, and individual households as well as foreign countries. There was involvement of foreign governments, bilateral and multilateral organizations, and INGOs. Such involvement of different parties is obviously weakening the NRA's power of directing/leading the reconstruction works. Moreover, coordination and communication challenges are inevitable. Eventually, the NRA seems weaker in the process of controlling and influencing the works of others, specifically the works of the donors because the reconstruction work is heavily dependent on donors' financial and nonfinancial resources.

The Reconstruction Act could not dictate the NRA to divide the reconstruction works at least into two categories - self and non-self-projects. If there was a demarcation between self and non-self-projects, it could be easier in the determination of authority and responsibility. Similarly, there are no more efforts paid by the Authority to provide real leadership in the reconstruction process. Neither it exercised control over the works of the donors and foreign countries, nor it remained far from their works. Similarly, the Authority could not gain momentum, even in physical reconstruction works in urban areas - mainly in Kathmandu Valley; and one of the impediments seems ineffective directing of the NRA to the concern authorities. Now, there may arise a question — who is responsible for the delays or derailments of the reconstruction worksthe NRA or the parties involved? Similarly, the Act could not assign the functions of real leadership to the Authority. The following table provides a summary of leading/directing assumptions.

Table 5

Directing/leading: Assumptions, Actions, and Achievements

\begin{tabular}{l}
\hline \multicolumn{1}{c}{ Basic assumptions } \\
\hline - Gives continuity to the national unity, harmony, and \\
tolerance \\
Ends the tendencies that could affect the social and religious \\
harmony (Guiding principle) \\
Orders the concern body to remove a physical structure, in \\
force, if necessary, for the reconstruction work (4.1.i) \\
Gives orders to remove or demolish the damaged or unsafe \\
physical structure to its owner; takes necessary action if the \\
owner does not remove or demolish the structure at his/her own \\
(4.1.q)
\end{tabular}

Note: The blank cells indicate no major actions and achievements regarding the corresponding assumptions

\section{Executing}

The NRA has spent most of its time for physical structures but not for national interest and social justice, which were instrumental to eco-cultural resilience. In fact, the vision and mission statement clearly insist for promotion of national interest, social justice, and resiliency. The projects such as Disaster Risk Reduction and Livelihood Restoration for Earthquake Affected Communities Project, Disaster Resilience School Project, Emergency School Reconstruction Project, are mainly for reconstruction of the schools not for eco-cultural resiliency enhancement by promoting national interest and enriching social justice. Likewise, the study could not find any livelihood programs started from the NRA on its own.

The Authority did not involve in reconstruction of schools. Instead, it wanted to get the work done through the School Management Committee; NGOs, Construction Companies; Ministry of Education, Central Project Implementation Units under different ministries. 
The NRA was not being effective enough to manage land for integrated settlements and translocation of affected people. However, the government was working to manage land for translocation of 648 beneficiaries. The translocation is continuous at a personal level as 1,199 individuals were getting land on their own at secured areas and they were getting Rs. 200,000 grants for doing so.

Table 6

Executing: Assumptions, Actions, and Achievements

\begin{tabular}{lll}
\hline \multicolumn{1}{c}{ Basic assumptions } & \multicolumn{1}{c}{ Major actions } & \multicolumn{1}{c}{ Notable achievements } \\
\hline $\begin{array}{l}\text { Implements or caused to be } \\
\text { implemented the plans and }\end{array}$ & Worked with governmental & Completed integrated \\
programs of integrated settlements, & and non-governmental & settlements-50 for 756 families \\
organizations &
\end{tabular}

house pooling, rehabilitation and

translocation (4.1.g)

Carries out, or caused to be carried out - Making technical

the reconstruction work (4.1.e)

manpower available

Carries out, or cause to be carried out, by mobilization of 374 reconstruction work in collaboration engineers, 391 subengineer, 336 assistant with the governmental, private or non-governmental sector, community or with any foreign organization based sub-engineers at district levels

- Completed the construction of eight model schools

- Construction completed individual houses till 20/03/2077: 507,623 in Nepal, by selecting the appropriate

- Expediting the modality (4.1.m) construction and retrofitting of physical structures

- Making agreements with 768,469 beneficiaries for individual homes construction

- Formation of committees at local level to expedite the reconstruction works

Executes, or caused to be executed, programs related to human resource development, reconstruction and rehabilitation as required for education, health, agriculture, industry, employment, and reconstruction and rehabilitation (4.1.j) Does, or cause to be done, other reconstruction related works in the earthquake affected area (4.1.s)
- Provided training on TOT, inspection manual, and correction manual to approximately 2, 500

- Provided training of carpentry, masonry, plumbing, etc. to 70,127
Availability of well-trained reconstruction technicians and workers including carpenter, masons, plumbers, etc. 


\section{Coordinating}

There were 202 non-governmental organizations involved in 293 projects under tripartite agreements with the NRA, NGOs, and concerned ministries/departments of the government in 2074/7. Such a number of organizations and projects reached 238 and 356 respectively in 2075/76. As the involvement of parties increases as increases the challenges in coordination.

The Authority could not provide and receive reliable and timely information concerning the policy, projects, programs, and its own working procedures due to delay in its establishment and formality complexity. Moreover, it could not develop a mechanism to ensure the continuous inputs mainly the construction materials, manpower, money (at subsidized loan/grants) for reconstruction works.

Capital expenditure could not be spent much more because of excessive time-consuming in preparing drawings, designs, and tendering. Involvement of various parties with plural interests was another challenge. However, interaction programs with various parties including the local and provincial public representatives were continuous.

Table 7

Coordinating: Assumptions, Actions, and Achievements

\begin{tabular}{lll}
\hline \multicolumn{1}{c}{ Basic assumptions } & \multicolumn{1}{c}{ Major actions } & \multicolumn{1}{c}{ Notable achievements } \\
\hline Coordinates with various bodies in & Establish policy, monitoring, & Involvement of at least 238 non- \\
order to make reconstruction work & evaluation and coordination & governmental organizations in \\
effective (4.1.n) & division, and & 356 reconstruction related works \\
& involved in coordination with & till 2075/76 \\
& different entities & \\
\hline
\end{tabular}

\section{Evaluating/monitoring}

The progress reports of the NRA couldn't exhibit efficient and effective mechanisms and facilities established and operationalized for evaluation/monitoring of the reconstruction works including the quality of construction materials. A robust mechanism for quality controls of construction materials could not be established and operationalized. Eventually, the quality of reconstructed structures itself is in a question mark even for structural sustainability and resiliency. Similarly, the Authority could not be in the position to establish a strong mechanism for evaluation of the works carried out by the NGOs, INGOs, donors, and foreign government agencies.

Moreover, an effective mechanism for coordination, facilitation, and monitoring could not be realized from the very beginning. Significance of such mechanisms at the local level was realized only in the year 2074/75; however, it could be established not only at the local level but a mechanism from the center to the local was necessary from the very beginning.

Progress of reconstruction works is not reflected in quantitative terms. At least, a report on what percentage of reconstruction works has been completed till the date of annual progress report preparation could be more meaningful. However, the progress report focuses on the tasks the NRA had carried out including the minutes of its all meetings.

NRA's tenure was specified for five years with the possibility of one-year extension. It has carried out numerous plans and programs but the absence of firm commitments for a specific time of completion. Almost all the plans and programs were flowing freely without a completion timeline with some exceptions. The annual progress reports do not reflect any scheduled commitments. A timeline could not become a criterion for performance evaluation of the NRA; but it became a criterion to receive tranches for private homes construction. 
Table 8

Evaluating/monitoring: Assumptions, Actions, and Accomplishments

\begin{tabular}{l}
\hline Basic assumptions \\
\hline Prevents any works done against-and/or gives order to work \\
under conformity with - the prescribed quality, standard or mode \\
(4.h) \\
Makes inspection, examination and monitoring, or cause to be \\
inspected, examined and monitored, the acts and actions done and \\
taken at the direction of the Authority (4.1.r) \\
Arranges, or cause to be arranged, for the effective utilization of \\
financial resources (4.1.p)
\end{tabular}

Note: The blank cells indicate no major actions and achievements regarding the corresponding assumptions

\section{Grievance handling}

Grievances were continuous even after completion of the household surveys. Surprisingly, the beneficiaries were 832,408 and grievances were 634,973 i.e. more than $76 \%$ of the beneficiaries were filing their complaints. In one way, a higher number of grievances (even to be included in the list of beneficiaries) is an indication of ineffective household surveys and information collection work. However, about $94 \%$ (1867/1993) rejection of grievance appeals indicates the role of unethical behavior and/or a deep-rooted self-interest of the people in which they just wanted to get available grants and support as much as possible.

Table 9

Grievance Handling: Assumptions, Actions, and Achievements

\begin{tabular}{|c|c|c|}
\hline Basic assumptions & Major actions & Notable achievements \\
\hline $\begin{array}{l}\text { Conducts public hearing at least } \\
\text { once in every six months (23) }\end{array}$ & & \\
\hline $\begin{array}{l}\text { Accepts the complaints and } \\
\text { grievances against the NRA }\end{array}$ & $\begin{array}{l}\text { - Set up of units and registered } \\
\text { the complaint/grievances }\end{array}$ & $\begin{array}{l}\text { - Grievances registered: } \\
634,973\end{array}$ \\
\hline$(26.1)$ & $\begin{array}{l}\text { Integrated grievances to the } \\
\text { MIS of NRA }\end{array}$ & - Grievances cleared: 634,973 \\
\hline $\begin{array}{l}\text { Grants the rights of appeal } \\
\text { against the decisions and actions } \\
(26.2)\end{array}$ & $\begin{array}{l}\text { Registered and processed the } \\
\text { appeals }\end{array}$ & $\begin{array}{l}\text { - Decision on the appeals till } \\
\text { 2076/12/05: } 1,993 \\
\text { - Rejected appeals till } \\
\text { 2076/12/05: } 1,867\end{array}$ \\
\hline
\end{tabular}

Note: The blank cells indicate no major actions and achievements regarding the corresponding assumptions

\section{Advising the government}

This study found no more advice to the government as such. However, the authority seems to advise the government in selected cases. Following table provides an example of its advice. 
Advising the Government: Assumptions, Actions, and Achievements

\begin{tabular}{lll}
\hline \multicolumn{1}{c}{ Basic assumptions } & \multicolumn{1}{c}{ Major actions } & \multicolumn{1}{c}{ Notable achievements } \\
\hline Makes recommendation to the & Made advices to declare & The government declared 14 \\
government for specification of the & highly affected, affected, and & highly affected, 11 affected, and \\
earthquake-affected area (4.1.b) & least affected districts & 7 least affected districts \\
\hline
\end{tabular}

\section{Assessment on the reconstruction process activities}

The pace of the reconstruction of physical structures remained quite slower than actually it should be to complete all the works in five years' tenure of the Authority. However, the work of geological surveys was encouraging. Under the convenorship of NRA, such surveys were completed in 117 human settlements in the first fiscal year 2072/73 and in 545 settlements in the second year 2073/74. Out of the 662 settlements, 136 were urgently requiring translocation.

Although, there was no concrete plan for translocation of the settlement from the NRA; but it had a provision of providing up to Rs 200,000 as grants for land purchase if any beneficiary intends to relocate from the high-risk settlement. In fact, the NRA should have concrete plans for translocation of the high risks' settlements, but the Ministry of Urban Development was working for it.

The pace of reconstruction was also adversely influenced by more than 634,973 grievances filed against the task of beneficiary identification. Apparently, additional time, personnel, and resources were required to handle the complaints/grievances. The following table provides a detail of the reconstruction works.

Table 12

Reconstruction works progress [As of FY 2075/76]

\begin{tabular}{|c|c|c|c|c|c|c|c|c|}
\hline \multirow{3}{*}{ Structures } & \multirow{3}{*}{$\begin{array}{c}\text { Damaged } \\
\text { number }\end{array}$} & \multicolumn{7}{|c|}{ Reconstruction works } \\
\hline & & \multirow{2}{*}{$\begin{array}{l}\text { Selected } \\
\text { Number }\end{array}$} & \multicolumn{2}{|c|}{ Completed } & \multicolumn{2}{|c|}{ Continuous } & \multicolumn{2}{|c|}{ Not started } \\
\hline & & & $\mathrm{N}$ & $\%$ & $\mathrm{~N}$ & $\%$ & $\mathrm{~N}$ & $\%$ \\
\hline Archeological property & 891 & 753 & 380 & 50.46 & 123 & 16.33 & 250 & 33.20 \\
\hline Gumbas & 1320 & 1320 & 1 & 0.08 & 1279 & 96.89 & 40 & 0.03 \\
\hline Schools & 7923 & 7523 & 5063 & 67.30 & 1516 & 20.15 & 944 & 12.55 \\
\hline Government buildings & 483 & 415 & 303 & 73.01 & 109 & 26.27 & 3 & 0.72 \\
\hline Health institutes & 1197 & 1197 & 665 & 55.55 & 149 & 12.45 & 383 & 32.00 \\
\hline Security force houses & & 383 & 183 & 47.78 & & & & \\
\hline $\begin{array}{l}\text { Drinking water and } \\
\text { sanitation }\end{array}$ & 3212 & & 791 & & 670 & & & \\
\hline
\end{tabular}

\section{Budgetary assessment}

The Authority's budget depended on the decisions and actions of the government and donor agencies. Nepal government's rules regarding public procurement, land acquisition, land registration, trusts, forests, ancient monuments, and environment seem directly and indirectly affecting the budgetary progress. Similarly, excessive time consumption in preparation of the drawing, designs, and tender documents remained other causes of affecting the speedy expenditure on reconstruction works. For instance, rules and regulations regarding land procurement standards, interest-free loans, and grievance handling procedures were formulated almost two years later in 2074 i.e. just after passing about $40 \%$ of total tenure of five years of the Authority. 
Table 13

Status of Financial Budget

\begin{tabular}{llcccc}
\hline Unit & Budget category & $2072 / 73$ & $2073 / 74$ & $2074 / 75$ & $2075 / 76$ \\
\hline \multirow{3}{*}{ Budget in Rs. } & Recurring & & 56.39 & 4.82 & 4.34 \\
Billion & Housing grants & & & 97.34 & 76.99 \\
& Capital & & 56.18 & 49.02 & 57.10 \\
& Total & 74.00 & 112.58 & 151.18 & 138.43 \\
& Recurring & & 67.37 & 65.18 & 77.97 \\
Expenses (\%) & Housing grants & & & 90.89 & 64.39 \\
& Capital & & 20.54 & 47.25 & 63.90 \\
& Total & 30.36 & 44.00 & 75.92 & 64.61 \\
\hline
\end{tabular}

Source: NRA

\section{Assessment on eco-cultural resiliency}

The objective of NRA is to promptly complete the reconstruction works of the structures damaged by the earthquake in a sustainable, resilient and planned manner to promote national interest and provide social justice. The works of reconstruction, resettlement, and translocation obviously demand more concrete plans and programs to address the objectives of resiliency, national interest and social justice. However, the study could not find such plans and programs in the annual progress reports of the Authority except a few exceptions about the resiliency of physical structures. The following table reflects the inference drawn from the contents of the reports.

Table 13

Eco-cultural Resiliency Assessment Framework

\begin{tabular}{|l|l|l|}
\hline \multicolumn{1}{|c|}{$\begin{array}{c}\text { Vulnerability } \\
\text { dimensions }\end{array}$} & \multicolumn{1}{|c|}{ Likely hazards } & \multicolumn{1}{c|}{ Remarks on resilience measures } \\
\hline $\begin{array}{l}\text { Physical } \\
\text { structures }\end{array}$ & $\begin{array}{l}\text { Almost all the physical structures that are not } \\
\text { covered by the reconstruction works in the } \\
\text { affected districts and beyond are still under the } \\
\text { risks }\end{array}$ & $\begin{array}{l}\text { The structures that have not been } \\
\text { addressed by the reconstruction works } \\
\text { require urgent actions to certify those } \\
\text { structures as earthquake resistant }\end{array}$ \\
\hline $\begin{array}{l}\text { Psychological } \\
\text { state }\end{array}$ & $\begin{array}{l}\text { People's increasing expectations of help } \\
\text { and supports for them from the donors and } \\
\text { government among the people } \\
\text { Downgrading ethical values and increasing } \\
\text { tendency of personal-benefit-seeking } \\
\text { among the actors }\end{array}$ & $\begin{array}{l}\text { No programs/initiatives for changing } \\
\text { attitude of people in favor of self- } \\
\text { reliant to the extent possible in the } \\
\text { districts including the conditions of } \\
\text { disaster and calamities }\end{array}$ \\
\hline
\end{tabular}


Issue 1 May/June 2020

\begin{tabular}{|c|c|c|}
\hline $\begin{array}{c}\text { Vulnerability } \\
\text { dimensions }\end{array}$ & Likely hazards & Remarks on resilience measures \\
\hline $\begin{array}{l}\text { Cultural } \\
\text { values }\end{array}$ & $\begin{array}{l}\text { Rapidly disappearing the items, places, } \\
\text { knowledge and skills of traditional } \\
\text { architectural structures, idols, handicrafts, } \\
\text { construction materials and processes, } \\
\text { instrumentation, and so on. } \\
\text { - Shortages of skilled manpower for } \\
\text { restoration works } \\
\text { Missing/disappearing typical components } \\
\text { of cultural configuration }\end{array}$ & $\begin{array}{l}\text { Restoring originality while doing } \\
\text { reconstruction works at the sites } \\
\text { of archaeological and cultural } \\
\text { significance. However, initiatives for } \\
\text { enhancing such skills are insufficient } \\
\text { as a resilience measure of the cultural } \\
\text { heritages }\end{array}$ \\
\hline $\begin{array}{l}\text { Financial } \\
\text { condition }\end{array}$ & $\begin{array}{l}\text { Excessive dependence on the donors for } \\
\text { funding development activities, no more } \\
\text { income generating activities in the areas }\end{array}$ & $\begin{array}{l}\text { No more use of local resources as most } \\
\text { of the construction materials were } \\
\text { transported from distance within and } \\
\text { outside of the country. }\end{array}$ \\
\hline
\end{tabular}

\section{Results}

The preamble of the Reconstruction Act clearly specifies the rationale of establishing the Authority as to promptly complete the reconstruction works of the structures damaged by the earthquake in a sustainable, resilient and planned manner, and to promote national interests and provide social justice by making resettlement and translocation of the persons and families displaced by the earthquake. The Authority's mandate consists of ten process activities - surveying, designing, planning, capacitating/ organizing, directing/leading, executing, coordinating, evaluating/monitoring, grievance handling, and advising the government of Nepal.

This study finds the process activities carried out by the Authority concentrated on the physical structures of reconstruction, resettlement and translocation works. Out of the ten process activities only three activities - surveying, coordinating, and advising the government of Nepal are maintaining nominal congruence among the assumptions, actions, and accomplishments. The remaining activities are not maintaining the congruence as there is presence of blank cells i.e. this study could not find the actions and achievements to commensurate the assumptions. The following table provides the level of nominal congruence.

Table 14

Status of objective-1: Level of Congruence

\begin{tabular}{lcccc}
\hline Process activities & Assumptions & Actions & Achievement & Congruence $\%$ \\
\hline Surveying & 3 & 3 & 3 & 100 \\
Designing & 6 & 5 & 5 & 90 \\
Planning & 5 & 2 & 2 & 60 \\
Capacitating & 6 & 3 & 3 & 67 \\
Directing & 3 & 0 & 0 & 0 \\
Executing & 4 & 3 & 3 & 83 \\
Coordinating & 1 & 1 & 1 & 100 \\
Evaluating & 3 & 0 & 0 & 0 \\
Grievance handling & 3 & 2 & 2 & 78 \\
Advising the government & 1 & 1 & 1 & 100 \\
Total & 35 & 20 & 20 & 71.42 \\
\hline
\end{tabular}


All the progress reports of the NRA do not exhibit weight to the Authority's decisions and actions. Consequentially, this study couldn't adopt the criteria of excellence with weightage of the targets and achievements for finding the weighted congruence. The level of nominal congruence of $71.42 \%$ among the assumptions, actions, and achievements concerning the consequential mission is very low. When nominal scale is used, normally more than $90 \%$ congruence is considered necessary (but, $100 \%$ can be expected because one must carry out actions to meet its obligations/ expectations known as assumptions, and when there is action addressing the assumption, then only the action results into an outcome known as achievement). Moreover, $100 \%$ congruence on one to one between the assumptions, actions, and achievements doesn't always indicate $100 \%$ success. Therefore, in a consequential mission, at least nominal congruence is expected at its upper limit. For instance, when one promise to do something, at least $\mathrm{s} / \mathrm{he}$ should initiate her/his action to meet the promise; and only the action taken to meet the obligation brings an outcome. This paper excludes the goodness of the assumptions, actions, and achievements, but attempts to find whether notable actions were taken to the notable assumptions for notable achievements or not.

Total $(100 \%)$ congruence is necessary to ensure the perseverance of the Authority to the assumptions. Mainly, the process activities of the Authority are only addressing the physical structures of reconstruction, resettlement, and translocation. The actions do not address the concerns of national interest, social justice, and reciprocal eco-cultural resiliency.

Partially adapted process activities and corresponding assumptions, actions, and achievements of the Authority seems insufficient to achieve the envisioned transformation in the disaster-affected districts. Deeply rooted self-interest of people and institutions associated with the consequential mission stands as a major challenge in the process of reconstruction.

The reconstruction process activities were passing through a number of constraints of regulatory documents as some of the documents were drafting and issuing even at the end of the tenure of the NRA (See Appendix 1). Multiplicity of interests of the parties involved in the works seems another challenge. Nevertheless, there were adequate actions seen in relation to the physical structural works, but no such tangible actions were seen in relation to the national interest promotion and social justice assurance except the grievance handling. As the annual progress reports of the NRA do not specify notable actions taken to address the Act's concerns of the national interest and social justice.

The study generates the knowledge that involvement of multiple people and institutions-largely dominated by their self-interest - in a resource-constrained mission that endangers the mission's leadership effectiveness, national interest, and social justice. Separation of the self-executing and non-self-executing project(s) as early as possible provides clear insights in the mobilization of resources. Balancing a particular timeline and performance at work is the best indicator of mission accomplishment.

Table 15

Status of the objective-1: The Reconstruction Process Activities

\begin{tabular}{ll}
\hline Key aspects of the mission & Status in the progress reports \\
\hline Reconstrucition works & Adequate actions seen \\
National interest promotion & No tangible actions seen \\
Social justice assurance & No actions seen (except the grievance handling) \\
\hline
\end{tabular}

The consequential mission initiated a large number of initiatives to strengthen the eco-cultural structures in the affected-districts. The notable initiatives such as integrated settlements, skills development programs, and livelihood enhancement programs seems instrumental in strengthening the eco-cultural structure. However, the practice of excessive financial dependence on the donors and foreign governments and institutions indicates a serious issue of weakening the eco-cultural setting. 
Table 16

Status of objective-2: Change and Development in Eco-cultural structure

\begin{tabular}{ll}
\hline Accomplishments & Eco-cultural structure \\
\hline Integrated settlements & Strengthening \\
Skills development & Strengthening \\
Livelihood enhancements & Strengthening \\
Excessive financial dependence on donors and & Weakening \\
foreign governments and institutions & \\
\hline
\end{tabular}

The vulnerability dimensions of physical structures, psychological state, cultural values, and financial condition have been observed with possibility of reciprocity. The dimensions of physical structures and financial condition were observed with high possibility of reciprocity. Whereas, the psychological dimension was observed a possibility of a medium reciprocity, whereas low possibility was observed in the dimension of cultural values.

Table 17

Status of Objective-3: Reciprocity in Eco-cultural Resiliency

\begin{tabular}{|c|c|c|}
\hline $\begin{array}{l}\text { Vulnerability } \\
\text { dimensions }\end{array}$ & Remarks on resilience measures & $\begin{array}{c}\text { Possibility of } \\
\text { reciprocity }\end{array}$ \\
\hline $\begin{array}{l}\text { Physical } \\
\text { structures }\end{array}$ & $\begin{array}{l}\text { The structures that have not been addressed by the reconstruction } \\
\text { works require to certify that those structures are earthquake resistant. } \\
\text { However, possibility of reciprocal interdependence among the key } \\
\text { actors seems high. }\end{array}$ & High \\
\hline $\begin{array}{l}\text { Psychological } \\
\text { state }\end{array}$ & $\begin{array}{l}\text { More programs/initiatives for changing attitude of people in favor of } \\
\text { self-reliance measures under the context of disaster and calamities. } \\
\text { High expectations of the affected people from outsiders and excessive } \\
\text { financial dependence of the NRA on the others were observed the } \\
\text { factors adversely affecting the attitude in favor of self-reliance. }\end{array}$ & Medium \\
\hline Cultural values & $\begin{array}{l}\text { Restoring originality while doing reconstruction works at the sites } \\
\text { of archaeological and cultural significance is satisfactory. However, } \\
\text { initiatives for preserving, enhancing, and promoting the knowledge } \\
\text { and skills for it are insufficient. The suppliers of the materials, items, } \\
\text { and skills to be used, dramatic shift of people in terms of valuing their } \\
\text { cultural attributes and artifacts, adverse impacts of cultural intruders, } \\
\text { among others were observed critical challenges for the possibility of } \\
\text { reciprocal interdependence. }\end{array}$ & Low \\
\hline $\begin{array}{l}\text { Financial } \\
\text { condition }\end{array}$ & $\begin{array}{l}\text { No more use of local resources as most of the construction materials } \\
\text { and labors were transported from distance within and outside of the } \\
\text { country. However, possibility of reciprocal interdependence among } \\
\text { the key actors was observed high. }\end{array}$ & High \\
\hline
\end{tabular}

The knowledge generated from the analysis of the assumptions, actions, and achievements within the managerial process activities points out very diversified areas and issues. Self-centered and vested-interest of the key actors and beneficiaries, regulatory formalities, ownership of the projects, and congruence 
between the saying and doing were observed most critical concerns to the mission accomplishment.

Table 18

The status of objective-4: Knowledge from the consequential mission

\begin{tabular}{ll}
\hline SN & \multicolumn{1}{c}{ The knowledge } \\
\hline 1 & $\begin{array}{l}\text { Self-centered/vested-interest increases the grievances, and decreases the self-efficacy and } \\
\text { performance of the real doers }\end{array}$ \\
2 & $\begin{array}{l}\text { Regulatory documentation and formalities are primary time taker of reconstruction works } \\
\text { A clear demarcation between self-executing and non-self-executing projects of reconstruction } \\
\text { with ownership specification at the very beginning is necessary. }\end{array}$ \\
4 & $\begin{array}{l}\text { One to one and/ or weighted congruence of the assumptions, actions, and achievements within the } \\
\text { managerial process activities is essential for a consequential mission accomplishment. }\end{array}$ \\
\hline
\end{tabular}

\section{Discussion}

The paper argues that the basic evidences to the assumptions is the Act itself, and the evidences to the actions and achievements are the NRA's annual progress reports. The Act and other regulatory documents (see Appendix 1)concerning the mission have made the Authority as a fulcrum; and every initiative of the reconstruction works, national interest promotion, and social justice assurance required to come under its purview. The laws have granted a legitimate power to the Authority for the mission accomplishment but did not disclose the concerns of institutional and strategic competence, legal adequacy and appropriateness, system realization and integration, technical/procedural capability and commitment/motivation of all involved in the mission.

Early completion of the reconstruction works, translocation and resettlement of displaced people, promotion of national interest, and assurance of social justice are the four pillars of the Reconstruction Act, 2015, under which the NRA is established. However, the delay in establishment of NRA caused a significant delay in completing the institutional formalities and formulating plans, policies, and directives. Lately introduced Reconstruction Act specifies the functions, duties, and power of the Authority required for physical structural works. But the Act neither defines the 'national interest' and 'social justice' nor specifies the functions, duties, and power to promote the national interest and provide social justice.

Subsequently, the actions of NRA have not addressed the concern of national interest, social justice, resilient/secured settlements and prosperous society as such as it addressed the physical structures. In the case of physical structures, it seems affected people focusing on their in-place rebuilding even if the ground is not safer for reconstruction. The efforts of shifting the people and schools to the location that are considered safer from natural disasters like earthquakes, landslides, floods, and so on deemed more challenging because of the people's emotional attachment to their native places as well as their reciprocal eco-cultural settings. In fact, if there were concrete plans and programs to address the novel concerns of national interest, social justice, and eco-cultural resiliency the consequential mission could be outstanding. In reality, all of the progress reports $(2073 / 74,2074 / 75,2075 / 76)$ of the NRA are missing these two integral parts of the mission.

NRA heavily involved donors and international agencies for reconstruction works including reconstruction of major heritages and public structures. Such involvement invited challenges of ensuring congruence of plural interests and coordination of multiple activities. Legacies and urgency of the parties involved requires special attention in disaster management (Curato, 2018) Moreover, some of the activities of foreign countries were continuous at their own discretion. For instance, the grant of about Rs. 75 billion from China was not coming to the government budget; but China spent the money directly to reconstruct schools, hospitals, and structures of archaeological significance. Similar cases were with the other countries' assistances including the USA and UK as well. 
Providing leadership in the reconstruction works seems challenging for the Authority. Coordination of multi-stakeholders, condition of resources constraints, dependency on the donors, and political appointments without committed-supports are seen as some of the major barriers for the leadership. The number of partner organizations was reached to 238 till the end of fiscal year 2075/76. As the number of partner organizations increased, it is obvious to follow multiple paths.

Basically, the Authority couldn't follow a particular path through its plan to the mission success. Instead, it adopted multiple paths mainly getting things done by oneself, through others, and having tripartite agreements among the NRA, government agencies and partner organizations mainly the INGOs and NGOs. It did not take responsibility for rebuilding the ancient settlements like Sankhu, Khokana, Bungmati, and so on. Instead, it intended to provide an additional Rs. 50,000 grants to restore the traditional originality while constructing private homes in the region. Even to rebuild the structures like Singha Durbar, Durbar Squares, it involved countries like Sri Lanka, India, China, Switzerland, Germany, USA, and others. The rebuilding of damaged structures, mainly the structures in Kathmandu Valley is still not getting momentum.

The pace of the reconstruction process is continuous in its own pace. In absence of standard time for the completion of reconstruction work, there are still many works to begin and complete at the end of the Authority's tenure. A firm commitment to a particular timeline was necessary for every project. The Authority did not divide its total works into five or six parts as the Reconstruction Act 2015 Section 3.3 had granted a mandate of $5+1$ years for completion of the entire reconstruction works.

The NRA selectively reports its annual progress in quantitative form. It does not report like what portion of its tenure has been completed and what portion of its works have been completed.

Livelihood programs were carried out in the earthquake-affected districts by the governmental and non-governmental organizations instead of the NRA. NRA's reports have ignored the fundamental issues of reciprocal eco-cultural resiliency such as the vulnerabilities of higher-economic status people, lowereconomic status people, house owners, business owners, individual renters, business renters, farmers, elderly people, children, and other demographic aspects of the people. In one way, post-disaster reconstruction in hazard-exposed areas can unintentionally amplify societal vulnerability beyond that which existed before the disaster (McCaughey, Daly, Mundir, Mahdi, \&Patt, 2018). The disputes and inability of people to rebuild their own homes or relocate for livelihood could be some examples of it.

The study argues reciprocal eco-cultural resilience as a moderator of vulnerability and immunity to post-disaster tragedies. Partially integrated planning premises, actions and commitments of the Authority combined with its decisions and actions were insufficient to achieve the envisioned transformation in the disaster-affected districts. Good social relationships and mutual help are instrumental in post-recovery of disaster, which has been exhibited exemplary in Nepal. People sheltered together in make-shifts, shared foods and emotions, built congenial relationships, and developed resiliency during the disaster (Bhattarai, 2016).

The ethical concerns are another aspect of reciprocal eco-cultural resiliency. For instance, Shailaja Pokharel, one of the victims of the earthquake of 2045 says "the earthquake completely damaged our home at Vijayapur Dharan. We didn't take the $100 \mathrm{Kg}$ rice given by the government as humanitarian relief because we were able to manage sufficient rice for our family at that time. Later, the government provided low-cost loans for private house construction, but we were not eligible to get that because we were not considered as a victim. If we had accepted the rice, then we would be considered as victims' '. Now, the tendency seems to have changed as people tend to take as much as benefits they can take without considering their right to get it. Increasing tendencies of violating ethical norms are challenging the concerns of social justice and eco-cultural resiliency.

Government fiscal and monetary policies are other concerns of eco-cultural resiliency. Absence of efforts to address the issues of inflation (as it increases as an increase in the inflow of money to the disaster areas during the rescue, relief, and reconstruction phases) and inadequate efforts to address the issues of interests on loans (as the victims are unable to afford for it) are damaging the eco-cultural resiliency in the 
disaster areas. Moreover, there are examples of removal of taxes (on construction materials) in the postdisaster recovery process (Rey, De, Leone, \& Gilbert, 2017); however, the NRA could not be instrumental in this regard to influence the government of Nepal.

The annual reports do not specify about the measures of eco-cultural resiliency, national interest promotion, and social justice assurance. The paper intends to bring the issues of not disclosing the level of conformance between saying and doing. For instance, if the national interest and social justice were primary concerns (clearly specified in the preamble of the Act) then why not to disclose their status in the progress reports, why not to disclose one on one conformance to the extent possible?

\section{Conclusions and Recommendations}

Self-centered plural interests of the concerned people and institutions in addition to the condition of resources constraint of the government of Nepal are major impediments of the reconstruction mission. An urgency of ensuring compatibility among the laws and policies of the country, the NRA, and the donors caused delays in the planning process. A substantially higher number of grievances distorted the perception of a large number of people and institutions.

The authority could not deliver a robust plan and strong leadership. The plans and programs prepared so far could not be committed to a particular timeline even for the physical structural works. The reports do not exhibit totalconformance except a few managerial process activities. It is very obvious that if there would be a robust plan and leadership effectiveness - the directing function - for instance, say site management works at urban areas like Bhaktapur would be effective enough, and the reconstruction works would be gaining its momentum in the region. The timeline of five years given to the NRA at its establishment period definitely had a sense, but still there are much more things to complete even after completion of the allocated period of five years to make the mission accomplished. If there would be a timeline maintained for its every assumption, action, and achievement, at least the beginning and completion of every initiatives, the annual progress reports would be differently drafted i.e. time could be one most significant indicators for the success of the mission along with the quantity of works done and to be done. The timeline specified for the purpose of issuing tranches cannot ensure the mission's respect to the time.

Moreover, the concerns of national interest, social justice, and resiliency could not be addressed as they could be addressed. Plural interests and preferences of all involved could not be complementary in the reconstruction work. The downgrading ethical standard of key stakeholders and excessive dependency on foreign donors are alarming the reciprocal eco-cultural resiliency.

Comprehensively clear Reconstruction Act, demarcation of self-executable and non-self-executable projects, a balance of particular timeline and performance at work, and compatible controls measures are basic recommendations for post-earthquake reconstruction work. Development and application of one to one and/ or weighted congruence of the assumptions, actions, and achievements concerning the managerial process activities of the consequential mission is essential.

In the end, it is expected that this paper shall draw attention of all concerned to include indicators and weight to the forthcoming regulatory documents, standards, working procedures as well as to theassumptions, actions, and achievements while being involved in a consequential mission like this.

\section{References}

Curato, N. (2018). From authoritarian enclave to deliberative space: governance logics in post disaster reconstruction. Disasters, 42(4), 635-654.

McCaughey, J. W., Daly, P., Mundir, I., Mahdi, S., \&Patt, A. (2018). Socio-economic consequences of postdisaster reconstruction in hazard-exposed areas. Nature Sustainability, 1, 38-43.

Rey, T., De, L. L., Leone, F., \& Gilbert, D. (2017). An integrative approach to understand vulnerability and resilience post-disaster: The 2015 cyclone Pam in urban Vanuatu as case study. Disaster Prevention and Management: An International Journal, 26(3), 259-275. 
Issue 1 May/June 2020

National Reconstruction Authority [NRA]. (2017). Annual Progress Report. Kathmandu: Nepal Reconstruction Authority, Government of Nepal.

Bhattarai, R. K. (2016). Empathetic actors strengthen organizational immunity to industrial crisis: Industrial actors' perception in Nepal. Outlines. Critical Practice Studies, 17(1), 109-128. 


\section{Appendix 1: Key regulatory documents, standards, and working procedures}

१. भूकम्पबाट प्रभावित संरचनाको पुननिर्माण सम्बन्धि ऐन, २०७२

२. भूकम्प प्रभावित संरचनाको पुननिर्माण सम्बन्धि नियमावली, २०७२

३. राष्टिय पुनर्निमाण तथा पुनस्स्थापना नीति, २०७२

४. भूकम्प पीडितहरुको लागि काठ उत्पादन, आपूर्ति र व्यवस्थापन निर्देशिका, २०७२

५. भूकम्पबाट प्रभावित संरचनाको पुननिर्माणको लागि जग्गा प्रात्ति सम्बन्धि कार्यविधि, २७२

६. भूकम्पवाट प्रभावित व्यक्तिको नाममा जग्गा दर्ता गर्ने सम्वन्धी कार्यविधि, २०७२

७. भूकम्पबाट प्रभावित संरचनाको पुननिर्माणको लागि वातावरणिय प्रभाव मूल्याङ्कन सम्बन्धी कार्यविधि, २०७२

८. भूकम्पबाट प्रभावित संरचनाको पुननिर्माण सम्वन्धी सार्वजनिक खरिद कार्यविधि, २०७२

९. भूकम्पवाट प्रभावित व्यक्तिको पुनर्वास तथा स्थानान्तरणको लागि वन क्षेत्रको जग्गा उपलवध गराउने सम्वन्धी कार्यविधि, २०७२

१०. पुनर्निम्माण र पुनस्थ्थापनाको लागि गैर सरकारी संस्था परिचालन सम्बन्धी कार्यविधि, २०७२

१ १. वातावरणीय प्रभाव, जग्गा प्राप्ति र सार्वजनिक खरिद सम्बन्धी कार्यविधि, २०७२

१२. जग्गा दर्ता गर्ने सम्बन्धी कार्यविधि, २०७२

१ ३. भूकम्प प्रभावित घरपरिवारलाई आवासीय घर पुनर्निमाणका लागि प्रदान गरिने पुनरकर्जा कार्यविधि, २०७२

१४. राष्ट्रिय पुनर्निमाण प्राधिकरण पुनरावेदन कार्यविधि, २०७३

१५. विद्यालय पुनर्निर्मान कार्यविधि, २०७३

१६६. भूकम्पवाट प्रभावित निजी आवास पुननिर्माण अनुदान वितरण कार्यविधि, २०७३

१७. जोखिमयुक्त वस्ती स्थानान्तरण तथा पुनस्थ्थापना सम्वन्धि कार्यविधि, २०७३

१८. तालिम सज्चालन तथा व्यवस्थापन निर्देशिका, २०७३

१९. पुनर्निर्माण सामुदायिक समिति सम्बन्धी निर्देशिका, २०७३

२०. सार्वजनिक खरिद (पहिलो संशोधन) र जग्गा दर्ता सम्बन्धी कार्यविधि, २०७३

२ १. पुनर्निर्माण कोष व्यवस्थापन तथा सश्चालन कार्यविधि, २०७३

२२. स्वयंसेवक परिचालन सम्बन्धी निर्देशिका, २०७३

२३. निजी आवास पुनर्निम्माण प्राविधिक निरीक्षण कार्यविधि, २०७३

२४. भूकम्पबाट प्रभावित निजी आवास पुनर्निर्माण अनुदान वितरण कार्यविधि, २०७३

२५. जोखिमयुक्त बस्ती स्थानान्तरण तथा पुनस्थापना सम्बन्धी कार्यविधि, २०७३

२६. भूकम्पपीडितलाई बसोवासयोग्य जग्गा खरिद सम्वन्धि मापदणड, २०७४

२७. पुननिर्माण सम्वन्धि गुनासो व्यवस्थापन कार्यविधि, २०७४

२८. सश्चार तथा वह्य पहुँच रणनिति, २०७४-२०७७

२९. जोखिम वर्गमा पर्ने भूकम्पबाट प्रभावित लाभग्राही पहिचान सम्वन्थी कार्यविधि, २०७४

३०. पुनर्निम्माण सम्बन्धी गुनासो व्यवस्थापन कार्यविधि, २०७४

३ १. सामुहिक जमानीमा निर्व्याजी ऋण उपलब्ध गराउने कार्यविधि, २०७४

३२. एकीकृत बस्ती विकास सम्बन्धी कार्यविधि २०७४

३३. जोखिम वर्गमा पर्ने भूकम्पबाट प्रभावित लाभग्राही पहिचान सम्वन्धी कार्यविधि, २०७४

३४. सहुलियतपूर्ण कर्जाका लागि ब्याज अनुदान सम्वन्धी एकीकृत कार्यविधि, २०७५

३५. एकिकृत बस्ती विकाश सम्वन्धी कार्यविधि, २०७५

३६. भूकम्पबाट प्रभावित गुम्बा/ बिहार/ स्तुपहरुको संरक्षण, जीर्णोद्वार तथा पुनर्निर्माण सम्वन्धी कार्यविधि, २०७५

३७. छुट तथा पुन: जाँच सर्वेक्षण कार्य सज्चालन सम्वन्धी कार्यविधि, २०७५

३८. निजी आवास पुनर्निमाण कार्यक्रम अन्तर्गत बनेका घरहरुका लागि हलुका काठ/स्टिल फ्रेम संरचना नियम पुस्तिका, २०७५

३९. सहुलियतपूर्ण कर्जाका लागि ब्याज अनुदान सम्बन्धी एकीकृत कार्यविधि, २०७५

४०. एकीकृत वस्ती विकास सम्बन्धी कार्यविधि, २०७५

४१. प्राविधिक खटिनु पूर्व बनेका घरहरुलाई निजी आवास पुनर्निर्माण अनुदान रकम उपलब्ध गराउने सम्वन्थी कार्यविधि, २०७६

४२. सम्पदा बस्तीका एकल व बहुस्वामित्वका निजी आवास पुनर्निर्माण सम्बन्धी कार्यबिधि, २०७६

४३. कन्टिन्जेन्सी रकम खर्च गर्ने कार्यबिधि, २०७७ 


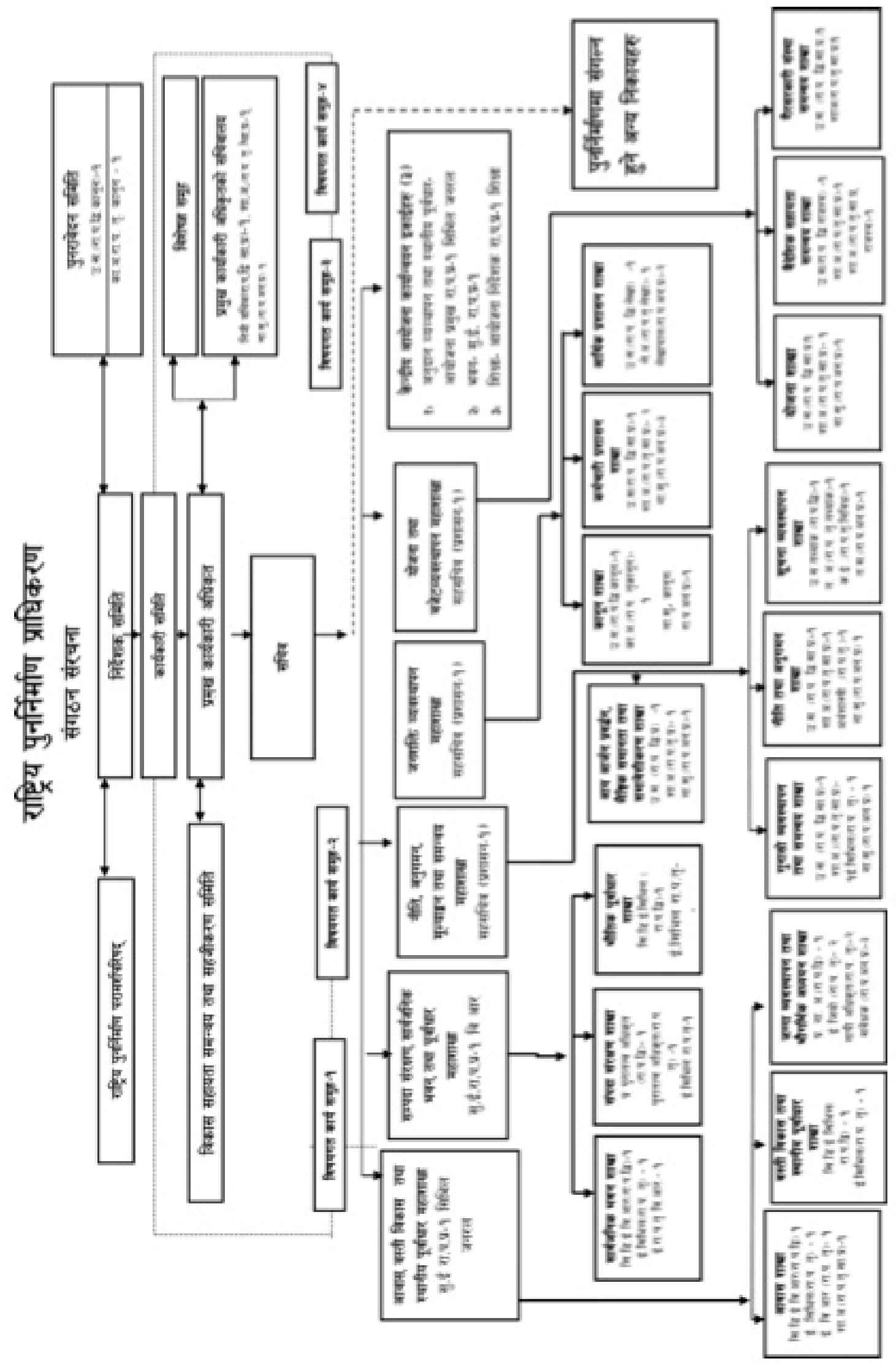

